\title{
FAKTOR-FAKTOR DOMINAN YANG BERPENGARUH TERHADAP PENGUASAAN MATERI PEMBELAJARAN MATEMATIKA GURU SMP DI KABUPATEN INDRAMAYU
}

\author{
Aan Juhana Senjaya \\ ${ }^{1}$ Universitas Wiralodra, Jalan Ir. H. Djuanda KM 3 Singaraja Indramayu, \\ aanjsenjaya@yahoo.com
}

\begin{abstract}
ABSTRAK
Penelitian ini bertujuan untuk mengetahui pengaruh persepsi terhadap matematika, kemampuan memahami simbol, penguasaan konsep dasar, dan motivasi belajar terhadap penguasaan materi pembelajaran matematika. Sampel penelitian terdiri dari 181 guru matematika SMP. Data dikumpulkan menggunakan kuisener dan tes. Data dianalisis dengan menggunakan analisis jalur dengan Structural Equation Modeling (SEM). Persepsi terhadap matematika sebagai variabel eksogen. Kemampuan memahami simbol, penguasaan konsep dasar matematika, dan motivasi belajar matematika sebagai variabel eksogen atau endogen tergantung pada diagram jalur. Variabel endogen adalah penguasaan materi pembelajaran matematika. Hasilnya menunjukkan bahwa: (a) persepsi terhadap matematika memiliki efek langsung positif terhadap kemampuan memahami simbol matematika $\left(\beta_{21}=0,63\right)$; penguasaan konsep dasar matematika $\left(\beta_{31}=50\right)$; motivasi belajar matematika $\left(\beta_{41}=0,38\right)$; dan penguasaan materi pembelajaran matematika $\left(\beta_{\mathrm{y} 1}=0,21\right)$; (b) kemampuan memahami simbol matematika memiliki pengaruh langsung positif terhadap penguasaan konsep dasar matematika $\left(\beta_{32}=\right.$ $0,23)$; motivasi belajar matematika $\left(\beta_{42}=0,27\right)$; dan penguasaan materi pembelajaran matematika $\left(\beta_{\mathrm{y} 2}=0,35\right)$; (c) penguasaan konsep dasar matematika memiliki pengaruh langsung positif terhadap motivasi belajar matematika $\left(\beta_{43}=0,26\right)$ dan penguasaan materi pembelajaran matematika $\left(\beta_{\mathrm{y} 3}=0,24\right)$; yang terakhir (d) motivasi belajar matematika memiliki pengaruh langsung positif terhadap penguasaan materi pembelajaran matematika $\left(\beta_{\mathrm{y} 4}=0,24\right)$.
\end{abstract}

Kata kunci: Persepsi Terhadap Matematika,

\section{ABSTRACT}

This study aims to determine the effect of perception toward math, ability of understand of symbols, mastery of basic concepts, and learning motivation toward the mastery of instructional materials of mathematics. The sample of study consisted of 181 Junior High School math teacher. Data were gathered using questionnaires and tests. Data were analyzed using path analysis with Structural Equation Modeling (SEM). The perception toward math as exogenous variable. The ability of understand of symbols, mastery of math basic concepts, and math learning motivation as exogenous or endogenous variable depend on the path diagram. The endogenous variables is the mastery of mathematics instructional materials. The finding showed that: (a) perception toward math have positive direct effect toward ability of understand of math symbol $\left(\beta_{21}=0,63\right)$; mastery of math basic concepts $\left(\beta_{31}=50\right)$; math learning motivation $\left(\beta_{41}=0,38\right)$; and mastery of math instructional materials $\left(\beta_{\mathrm{y} 1}=0,21\right)$; (b) ability of understand of math symbol have positive direct effect toward mastery of math basic concepts $\left(\beta_{32}=0,23\right)$; math learning motivation $\left(\beta_{42}=0,27\right)$; and mastery of math instructional materials $\left(\beta_{\mathrm{y} 2}=0,35\right)$; (c) mastery of math basic concepts have positive direct effect toward math learning motivation $\left(\beta_{43}=0,26\right)$ and to mastery of instructional materials of math $\left(\beta_{\mathrm{y} 3}=0,24\right)$; the last (d) math learning motivation have positive direct effect toward mastery of math instructional materials $\left(\beta_{\mathrm{y} 4}=0,24\right)$.

Keywords: Perception Toward Math, Ability of Understand of Math Symbols, Mastery of Math Basic Concepts, Math Learning Motivation, Mastery 
Kemampuan Pemahaman Simbol Matematika, Penguasaan Konsep

Dasar Matematika, Motivasi

Belajar Matematika, Penguasaan

Materi Pembelajaran Matematika.

How to Cite: Senjaya, A. J. (2017). Faktor-faktor Dominan yang Berpengaruh Terhadap Penguasaan Materi Pembelajaran Matematika Guru SMP di Kabupaten Indramayu. Mathline: Jurnal Matematika dan Pendidikan Matematika, Vol.2, No.2, 133-144.

\section{PENDAHULUAN}

Dalam kehidupan ini, setiap peristiwa dan gejala saling berinteraksi dan berkolerasi satu sama lainnya. Oleh karena itu, pencapaian penguasaan materi pembelajaran matematika sebagai salah satu kompetensi yang harus dimiliki oleh guru SMP, ditentukan dan saling berhubungan dengan faktor-faktor lainnya.

Banyak faktor yang mempengaruhi penguasaan materi pembelajaran matematika tersebut. Peneliti memilih beberapa faktor yang diduga berpengaruh dominan terhadap penguasaan materi pembelajaran matematika SMP serta dimungkinkan untuk memanipulasinya. Faktor-faktor tersebut adalah: (1) persepsi terhadap matematika; (2) kemampuan memahami simbol; (3) penguasaan konsep dasar; (4) motivasi belajar, dan (5) penguasaan materi pembelajaran matematika.

Unsur-unsur dalam matematika merupakan simbol-simbol yang dapat dipelajari melalui berbagai cara, seperti menghapal, latihan, praktek, percobaan berulang, permainan, dan perlombaan. Orang yang dianggap telah mempelajari unsur-unsur ini, adalah orang yang dapat menyatakan dan menggunakan suatu unsur dengan tepat pada berbagai situasi yang berbeda. Apabila seseorang mempersepsikan bahwa matematika terdiri dari simbolsimbol yang tidak menarik untuk dipelajari, maka tentu besar kemungkinan orang tersebut tidak akan berupaya untuk mempelajarinya, Dengan demikian, dia tidak akan memiliki kemampuan untuk memahami simbol-simbol matematika. Kesalahan mempersepsi matematika yang terdiri dari simbol-simbol, berkaitan dengan kemampuan membaca simbol matematik (Samo, 2008). Saat mempelajari matematika, melihat simbol tidak hanya sebagai angka, tapi melihat dan menyalinnya. Dalam belajar matematika, bukan hanya mendengar urutan bilangan secara lisan, namun mendengar dan melanjutkan urutan. Mempelajari matematika, bukan melihat atau mendengar saja, tetapi merupakan diskriminasi dan interpretasi penglihatan dan pendengaran (Tella, 2007). Dengan 
demikian, guru matematika yang mempersepsi bahwa matematika merupakan bahasa simbol, ia akan memiliki kemampuan untuk memahami simbol-simbol dalam matematika.

Dalam matematika definisi merupakan sistem terminologi seperti kalimat, simbol, atau rumus matematika yang menunjukkan gejala yang dimaksud oleh definisi. Definisi matematis mengungkapkan konsep matematis dalam bentuk lain secara lengkap dan bermakna dikaitkan dengan konsep matematis yang telah didefinisikan terlebih dahulu, dan juga konsep-konsep sederhana sebelumnya yang tak mudah didefinisikan dalam bentuk istilah dan operasi logika lain (FrameFan, 2013)

Jika seseorang mempersepsi matematika sebagai sesuatu yang menyenangkan, banyak kegunaannya, dan memiliki kepercayaan diri dapat mempelajari dan menguasainya, maka ia akan memiliki hasrat yang tinggi dalam mempelajari matematika. Pengalaman sukses juga memiliki titik balik untuk membuat pilihan belajar matematika secara sadar. Tujuan pendidikan mengharuskan untuk belajar matematika. Dipercaya bahwa jika kemampuan ditempa dan berupaya, maka bisa belajar matematika. Karena tujuan dan pertumbuhan pola pikir, maka secara instrinsik menjadi motivasi. Keinginan belajar untuk memahami, diperlukan untuk kemajuan pendidikan dan untuk pengalaman hidup (Howard, 2008).

Terdapat korelasi positif antara konsep diri sikap siswa terhadap matematika; dan terdapat korelasi positif antara sikap siswa terhadap matematika dengan prestasi belajar matematika (Kemboi et.al., 2014). Ada hubungan positif yang kuat antara keyakinan-diri terhadap matematika dan prestasi dalam matematika. Keyakinan-diri akan kemampuan belajar matematika merupakan komponen penting dari motivasi dan prestasi akademik (Tella, 2007) Terdapat korelasi yang signifikan antara konsep diri matematis dengan prestasi belajar matematika, prestasi akademik, dan konsep diri akademik (Obilor, 2011). Dengan demikian, persepsi terhadap matematika berpengaruh langsung positif terhadap penguasaan materi pembelajaran matematika.

Untuk mempelajari konsep matematika, siswa perlu berlatih membaca untuk memahami konsep. Ide matematika yang dinyatakan dalam simbol-simbol secara tertulis (Mutodi \& Ngirande, 2014). Peningkatan kerja dan skor tes sehari-hari terjadi setelah mengembangkan pemahaman tentang bahasa yang digunakan dalam matematika Jika siswa langsung diajar dengan bahasa matematika dalam berbagai cara, mereka dapat mengembangkan pemahaman yang lebih baik dari konsep-konsep matematika (Lawellen, 
2008). Dengan demikian, seseorang yang menguasai bahasa matematika akan mampu memahami simbol sesuai dengan makna dan kegunaannya.

Membaca materi matematika terbukti efektif dalam membantu siswa memahami materi (Else, 2008). Penggunaan bahasa matematika dan mempraktekannya, baik dalam bentuk tertulis maupun lisan, akan meningkatkan pemahaman isi buku teks, peningkatan kosakata, dan juga meningkatkan pemahaman pembelajaran matematika. Materi matematika dapat diingat dengan lebih baik bila bahasa matematika dan istilah digunakan secara tetap. Ditemukan juga bahwa perasaan lebih nyaman menggunakan kosakata matematika ketika dapat memahaminya (Buchanan, 2007).

Salah satu hal yang dapat mempengaruhi motivasi belajar seseorang adalah pengalaman masa lalunya dalam kontek yang sama. Jika seseorang mempunyai pengalaman masa lalu sukses dalam suatu kegiatan tertentu, ia sangat dimungkinkan memiliki harapan berhasil dalam kegiatan yang sama pada masa yang akan datang. Jadi, dapat dianalogikan bahwa jika seseorang merasa mampu menguasai konsep dasar matematika, maka ia akan merasa bakal mampu untuk belajar matematika selanjutnya. Dengan demikian, harapan ini akan menjadi dorongan atau motivasi untuk belajar. Ada tiga faktor yang mempengaruhi motivasi belajar, yaitu: Kepercayaan diri, pengalaman sukses dan kepuasan, dan hubungan baik antara guru dan siswa (Ebata, 2008).

Mengenai pengaruh penguasaan konsep dasar terhadap penguasaan materi ajar, analoginya adalah bahwa terdapat hubungan positif antara pengetahuan konsep dasar matematika dengan kemampuan menyelsesaikan masalah-masalah (Wenno, 2015). Terdapat hubungan yang signifikan antara penguasaan konsep dasar diferensial dan integral dengan prestasi belajar pada materi kinematika dengan analisis vektor (Rohman \& Effendi, 2014). Adapun Windhani \& Hardoyono (2012) menyimpulkan hasil penelitiannya bahwa terdapat keterkaitan antara kemampuan konsep matematis ketika sekolah di SLTA dengan kemampuan konsep matematik di perguruan tinggi.

Tentang pengaruh motivasi belajar teradap penguasaan materi pembelajaran matematika dapat mengambil analogi dari beberapa hasil penelitian yang menunjukan bahwa: (1) siswa yang diberi perlakuan (dimotivasi), prestasi belajarnya lebih baik daripada yang tidak diberi motivasi. Dengan demikian, motivasi belajar berpengaruh terhadap prestasi belajar (Alrabai, 2014). Orientasi motivasi siswa berkorelasi positif terhadap prestasi sains (Jen \& Yong, 2013). Motivasi berkorelasi positif dengan prestasi belajar (Awan, et.al., 2011). terdapat hubungan positif motivasi belajar dengan prestasi 
belajar; siswa yang motivasi belajarnya tinggi, prestasi belajar matematikanya lebih tinggi daripada siswa yang motivasi belajarnya rendah (Tella, 2007).

Tujuan penelitian ini adalah untuk mengetahui: (1) pengaruh langsung positif persepsi terhadap matematika terhadap kemampuan memahami simbol matematika; (2) pengaruh langsung positif persepsi terhadap matematika terhadap penguasaan konsep dasar matematika; (3) pengaruh langsung positif persepsi terhadap matematika terhadap motivasi belajar matematika; (4) pengaruh langsung positif persepsi terhadap matematika terhadap penguasaan materi pembelajaran matematika; (5) pengaruh langsung positif kemampuan memahami simbol matematika terhadap penguasaan konsep dasar matematika; (6) pengaruh langsung positif kemampuan memahami simbol matematika terhadap motivasi belajar matematika; (7) pengaruh langsung positif kemampuan memahami simbol matematika terhadap penguasaan materi pembelajaran matematika; (8) pengaruh langsung positif penguasaan konsep dasar matematika terhadap motivasi belajar matematika; (9) pengaruh langsung positif penguasaan konsep dasar matematika terhadap penguasaan materi pembelajaran matematika; dan (10) pengaruh langsung positif motivasi belajar matematika terhadap penguasaan materi pembelajaran matematika.

\section{METODE PENELITIAN}

Pendekatan penelitian menggunakan pendekatan kuantitatif. Jenis penelitiannya termasuk ke dalam penelitian survey. Metode penelitian yang digunakan adalah metode Kuantitatif assosiatif. Populasi subjek penelitian adalah seluruh guru matematika SMP di kabupaten Indramayu sebanyak 307 orang yang tersebar di 5 wilayah kerja Musyawarah Guru Mata Pelajaran (MGMP) matematika di kabupaten Indramayu. Wilayah kerja ini kemudian dijadikan cluster. Sampel penelitian diambil sebanyak 181 orang guru matematika SMP menggunakan teknik Cluster Proportional random sampling.

Data dikumpulkan menggunakan 2 jenis instrumen, yaitu berupa: (1) tes untuk pengumpulan data kemampuan memahami simbol matematika $\left(\mathrm{X}_{2}\right)$, penguasaan konsep dasar matematikan $\left(\mathrm{X}_{3}\right)$, dan penguasaan materi pembelajaran matematika $(\mathrm{Y})$; (2) kuisener untuk persepsi terhadap matematika $\left(\mathrm{X}_{1}\right)$ dan motivasi belajar matematika $\left(\mathrm{X}_{4}\right)$. Instrumen yang digunakan telah diuji coba dengan kriteria validitas $r \geq 0,20$ dan kriteria reliabilitas $r \geq$ 0,60. Teknik analisis data menggunakan Analisis Jalur (Path Analysis) melalui Structural Equation Modeling (SEM). Perhitungan statistik menggunakan Software LISREL 8.80 Full Version dan dibantu dengan cara manual (by tumb), MS-EXCEL dan SPSS Versi 23. 


\section{HASIL DAN PEMBAHASAN}

\section{HASIL PENELITIAN}

Temuan penelitian digambarkan pada gambar struktur jalur berikut:

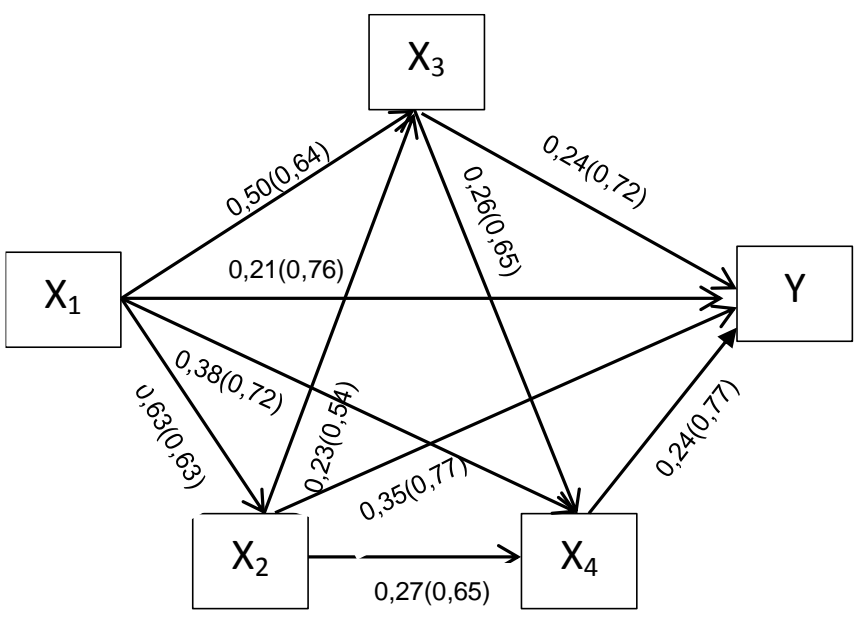

Gambar 1. Koefisien pengaruh dan korelasi pada jalur (path) Persepsi terhadap Matematika $\left(\mathrm{X}_{1}\right)$, Kemampuan Memahami Simbol $\left(\mathrm{X}_{2}\right)$, Penguasaan Konsep Dasar $\left(\mathrm{X}_{3}\right)$, Motivasi Belajar $\left(\mathrm{X}_{4}\right)$, dan Penguasaan Materi Pembelajaran Matematika (Y)

Berdasarkan Gambar 1, nampak bahwa: (1) persepsi terhadap matematika berpengaruh langsung positif terhadap kemampuan memahami simbol matematika ( $\beta_{21}=0,63$ dengan $r_{12}=0,63$ ); (2) persepsi terhadap matematika berpengaruh langsung positif terhadap penguasaan konsep dasar matematika $\left(\beta_{31}=0,50\right.$ dengan $\left.r_{13}=0,64\right)$; (3) persepsi terhadap matematika berpengaruh langsung positif terhadap motivasi belajar matematika ( $\beta_{41}=0,38$ dengan $\left.\mathbf{r}_{14}=0,72\right)$; (4) persepsi terhadap matematika berpengaruh langsung positif terhadap penguasaan materi pembelajaran matematika $\left(\beta_{\mathrm{y} 1}=0,21\right.$ dengan $\left.\mathrm{r}_{1 \mathrm{y}}=0,76\right) ;(5)$ kemampuan memahami simbol matematika berpengaruh langsung positif terhadap penguasaan konsep dasar matematika $\left(\beta_{32}=0,23\right.$ dengan $\left.r_{23}=0,54\right)$; (6) kemampuan memahami simbol matematika berpengaruh langsung positif terhadap motivasi belajar matematika $\left(\beta_{42}=0,27\right.$ dengan $\left.r_{24}=0,65\right)$; (7) kemampuan memahami simbol matematika berpengaruh langsung positif terhadap penguasaan materi pembelajaran matematika ( $\beta_{\mathrm{y} 2}=0,35$ dengan $\left.\mathrm{r}_{2 \mathrm{y}}=0,77\right)$; (8) penguasaan konsep dasar matematika berpengaruh langsung positif terhadap motivasi belajar matematika $\left(\beta_{43}=0,26\right.$ dengan $\left.r_{34}=0,65\right)$; (9) penguasaan konsep dasar matematika berpengaruh langsung positif terhadap penguasaan materi pembelajaran matematika $\left(\beta_{\mathrm{y} 3}=0,24\right.$ dengan $\left.\mathrm{r}_{3 \mathrm{y}}=0,72\right)$; dan (10) motivasi belajar 
matematika berpengaruh langsung positif terhadap penguasaan materi pemebelajaran matematika $\left(\beta_{\mathrm{y} 4}=0,24\right.$ dengan $\left.\mathrm{r}_{4 \mathrm{y}}=0,77\right)$.

\section{PEMBAHASAN}

Temuan pertama dari penelitian ini menunjukkan bahwa persepsi terhadap matematika berpengaruh langsung positif terhadap kemampuan memahami simbol matematika. Artinya, variasi kemampuan memahami simbol matematika dapat dijelaskan oleh variasi persepsi terhadap matematika. Temuan ini mendukung pendapat Suriasumantri (2010); Goldstone, et.al. (2008);

Persepsi seseorang atas sesuatu akan mempengaruhi pemahaman orang tersebut terhadap apa yang dipersepsinya. Temuan penelitian ini sejalan dengan hasil penelitian Susuwele yang menyampaikan bahwa persepsi guru atas asesmen matematika di kelas berpengaruh terhadap pelaksanaan mengajar di kelas Susuwele (2005); Samo (2008). Dengan demikian, variasi kemampuan memahami simbol matematika para guru matematika SMP dipengaruhi oleh variasi persepsi mereka terhadap matematika.

Temuan kedua penelitian ini menunjukan bahwa persepsi terhadap matematika memiliki pengaruh langsung positif terhadap penguasaan konsep dasar matematika. Dengan demikian, variasi penguasaan konsep dasar matematika dapat dijelaskan oleh persepsi terhadap matematika. Persepsi terhadap matematika dapat diamati dari tanggapan tentang matematika baik karakteristik materi maupun isi. Temuan ini sejalan dengan temuan Lawellen (2008) serta Simonson \& Gouvea (2015); Begitu juga dengan hasil temuan Simonson \& Gouvea yang menyatakan bahwa keindahan sebuah artikel matematika terletak pada cara menggambarkan ide-ide yang kompleks dengan cara yang sangat efisien, cepat, tepat, dan elegan. Oleh karena itu, guru matematika yang mempersepsi bahwa matematika merupakan bahasa simbol, maka ia akan memiliki kemampuan untuk memahami simbol-simbol matematika.

Temuan penelitian ketiga adalah bahwa persepsi terhadap matematika memiliki pengaruh langsung positif terhadap motivasi belajar matematika. Temuan ini mendukung pendapat McDonald yang dikutip Sardiman (2010) dan Howard (2008). Berdasarkan temuan ini berarti variasi motivasi belajar matematika para guru matematika SMP dipengaruhi oleh variasi mereka atas persepsi terhadap matematika.

Temuan keempat dari penelitian ini adalah bahwa persepsi terhadap matematika berpengaruh langsung positif terhadap penguasaan materi pembelajaran matematika. Artinya, variasi penguasaan materi pembelajaran matematika dapat dijelaskan oleh variasi persepsi terhadap matematika. Temuan ini mendukung pendapat Howey (2014), Kemboi 
et.al. (2014), serta Ayatolla \& Adedejib (2009). Oleh karena itu, berdasarkan temuan penelitian ini, dapat dinyatakan bahwa variasi penguasaan materi pembelajaran matematika para guru matematika SMP dipengaruhi oleh variasi mereka terhadap nateri atau isi, nilai dan kegunaan, cara mempelajari, dan orang-orang yang dianggap akan mampu mempelajari matematika.

Temuan kelima dari penelitian ini adalah bahwa kemampuan memahami simbol matematika berpengaruh langsung positif terhadap penguasaan konsep dasar matematika. Temuan ini mendukung pernyataan bahwa dalam matematika, pada umumnya, konsep dibangun dari definisi. Sejalan dengan temuan penelitian Lawellen (2008) dan pendapat Spagnolo (2015). Oleh arena itu, dapat dikatakan bahwa penguasaan konsep dasar matematika para guru matematika SMP dipengaruhi secara langsung oleh kemampuan mereka memahami simbol matematika.

Temuan keenam dari penelitian ini adalah bahwa kemampuan memahami simbol matematika memiliki pengaruh langsung positif terhadap motivasi belajar matematika. Temuan penelitian ini mendukung pendapat Ebata (2008) yang menyatakan bahwa ada tiga faktor yang mempengaruhi motivasi belajar, yaitu: Kepercayaan diri, pengalaman sukses dan kepuasan, dan hubungan baik antara guru dan siswa (Ebata, 2008). Apabila guru matematika SMP mampu memahami simbol matematika, maka ia akan merasa mudah untuk mempelajari setiap materi matematika. Karena merasa mudah, ia akan merasakan kesenangan dan memiliki hasrat yang tinggi untuk mempelajarinya.

Temuan ketujuh penelitian ini adalah bahwa kemampuan memahami simbol matematika berpengaruh langsung positif terhadap penguasaan materi pembelajaran matematika. Temuan ini sejalan dengan hasil penelitian Else (2008) yang meneliti pengaruh pembelajaran membaca buku teks matematika terhadap pemahaman materi aljabar dan trigonometri. Hasil penelitiannya menyimpulkan bahwa membaca buku merupakan strategi yang efektif untuk meningkatkan pemahaman materi matematika. Temuan penelitian ini, juga sejalan dengan hasil penelitian Buchanan (2007) yang menunjukan bahwa penggunaan bahasa matematika sehari-hari dan mempraktekannya, baik dalam bentuk tertulis dan lisan, meningkatkan pemahaman buku teks, peningkatan kosakata, dan juga meningkatkan pemahaman pembelajaran matematika (Buchanan, 2007). Oleh karena itu, pada guru matematika SMP, kemampuan memahami simbol matematika akan berpengaruh langsung positif terhadap penguasaan materi pembelajaran matematika. 
Temuan kedelapan penelitian ini adalah bahwa penguasaan konsep dasar matematika berpengaruh langsung positif terhadap motivasi belajar matematika. Hal ini sejalan dengan penelitian Ebata (2008). Apabila guru matematika SMP mampu menguasai konsep dasar matematika sejak awal, maka ia akan merasa mudah untuk mempelajari setiap materi matematika berikutnya. Karena merasa mudah, ia akan merasakan kesenangan dan memiliki hasrat yang tinggi untuk mempelajarinya.

Temuan kesembilan penelitian ini adalah bahwa penguasaan konsep dasar matematika berpengaruh langsung positif terhadap penguasaan materi pembelajaran matematika. Temuan penelitian ini sejalan dengan temuan penelitian Wenno yang menyatakan bahwa terdapat hubungan positif antara pengetahuan konsep dasar matematika dengan kemampuan siswa menyelesaikan masalah-masalah fisika (Wenno, 2015); Terdapat hubungan yang signifikan antara penguasaan konsep dasar diferensial dan integral dengan prestasi belajar siswa pada materi kinematika dengan analisis vector (Rohman \& Effendi, 2014); Terdapat keterkaitan antara kemampuan konsep matematis ketika sekolah di SLTA dengan kemampuan konsep matematik di perguruan tinggi (Windhani \& Hardojono, 2012). Implikasi untuk penelitian ini adalah bahwa penguasaan konsep dasar matematika guru SMP berpengaruh langsung posiyif terhadap penguasaan materi pembelajaran matematika SMP.

Temuan kesepuluh penelitian ini adalah bahwa motivasi belajar matematika berpengaruh langsung positif terhadap penguasaan materi pembelajaran matematika. Temuan penelitian ini sejalan dengan temuan penelitian yang dilakukan oleh beberapa peneliti seperti penelitian Alrabai (2014), Jen \& Yong (2015), Tella (2007), serta Awan, et.al. (2011). Oleh karena itu, dapat dinyatakan bahwa motivasi belajar berpengaruh positif langsung terhadap hasil belajar. Implikasinya pada penelitian ini adalah bahwa para guru matematika SMP yang memiliki motivasi belajar tinggi, maka penguasaan materi pembelajarannya juga akan tinggi.

Temuan lain penelitian ini, selain dari kesepuluh temuan yang berkaitan langsung dengan pengujian hipotesis adalah bahwa terdapat pengaruh persepsi terhadap matematika, kemampuan memahami simbol matematika, penguasaan konsep dasar matematika, dan motivasi belajar matematika secara bersama-sama terhadap penguasaan materi pembelajaran matematika. Artinya, apabila guru matematika memiliki persepsi yang baik terhadap matematika, memahami makna simbol-simbol matematika, menguasai konsep dasar matematika, dan memiliki motivasi belajar matematika yang tinggi, maka penguasaan materi pembelajarannya akan baik pula. 


\section{KESIMPULAN}

Sesuai dengan rumusan masalah, kajian teori, dan hasil penelitian, maka dapat disimpulkan bahwa:

1. Persepsi terhadap matematika berpengaruh langsung positif terhadap kemampuan memahami simbol matematika. Artinya, apabila persepsi terhadap matematika meningkat, maka kemampuan memahami simbol matematika juga akan meningkat.

2. Persepsi terhadap matematika berpengaruh langsung positif terhadap penguasaan konsep dasar matematika Artinya, apabila persepsi terhadap matematika meningkat, maka kemampuan penguasaan konsep dasar matematika juga akan meningkat.

3. Persepsi terhadap matematika berpengaruh langsung positif terhadap motivasi belajar matematika. Artinya, apabila persepsi terhadap matematika meningkat, maka motivasi belajar matematika juga akan meningkat.

4. Persepsi terhadap matematika berpengaruh langsung positif terhadap penguasaan materi pembelajaran matematika. Artinya, apabila persepsi terhadap matematika meningkat, maka kemampuan penguasaan materi pembelajaran matematika juga akan meningkat.

5. Kemampuan memahami simbol matematika berpengaruh langsung positif terhadap penguasaan konsep dasar matematika. Artinya, apabila kemampuan memahami simbol meningkat, maka kemampuan penguasaan konsep dasar matematika juga akan meningkat.

6. Kemampuan memahami simbol matematika berpengaruh langsung positif terhadap motivasi belajar matematika. Artinya, apabila kemampuan memahami simbol matematika meningkat, maka motivasi belajar matematika juga akan meningkat.

7. Kemampuan memahami simbol matematika berpengaruh langsung positif terhadap penguasaan materi pembelajaran matematika. Artinya, apabila kemampuan memahami simbol matematika meningkat, maka penguasaan materi pembelajaran matematika juga meningkat.

8. Penguasaan konsep dasar matematika berpengaruh langsung positif terhadap motivasi belajar matematika. Artinya, apabila penguasaan konsep dasar matematika meningkat, maka motivasi belajar matematika juga meningkat.

9. Penguasaan konsep dasar matematika berpengaruh langsung positif terhadap penguasaan materi pembelajaran matematika. Artinya, apabila penguasaan konsep dasar matematika meningkat, maka penguasaan materi pembelajaran matematika juga meningkat. 
10. Motivasi belajar matematika berpengaruh langsung positif terhadap penguasaan materi pembelajaran matematika. Artinya, apabila motivasi belajar matematika meningkat, maka penguasaan materi pembelajaran matematika juga meningkat.

\section{DAFTAR PUSTAKA}

Alrabai, F. (2014). The Effects Of Teachers' In-Class Motivational Intervention On Learners' EFL Achievement. Applied Linguistics, Volume 37, Issue 3, 1 June 2016, Pages 307-333.

Awan, R., Noureen, G., \& Naz, A. (2011). A Study of Relationship between Achievement Motivation, Self Concept and Achievement in English and Mathematics at Secondary Level. International Education Studies, Vol 4 No.3, page 72-79.

Ayatolla, A, \& Adedejib,T. (2009). The relationship between mathematics self-efficacy and achievement in mathematics. World Conference Education Science 2009. Procedia Social and Behavioral Sciences 1 (2009) 953-957.

Buchanan, T. (2007). The Importance of Teaching Students How to Read to Comprehend Mathematical Language. Action Research Projects, Paper 5. [Online]. Tersedia di: http://digitalcommons.unl.edu/ [Diakses 10 Juli 2015].

Ebata, M. (2008). Motivation Factors in Language Learning. The Internet TESL Journal, XIV(4). [Online]. Tersedia di: http://iteslj.org/ [Diakses 15 Juli 2015].

Else, M. (2008). Reading as a Learning Strategy for Mathematics. Action Research Projects, Paper 77: 20. [Online]. Tersedia di: http://digitalcommons.unl.edu/ [Diakses 10 Juli 2015].

FrameFan. (2013). Definition. [Online]. Tersedia di: http://planetmath.org/ [Diakses 10 Juli 2015].

Goldstone, R, Landy, D, \& Son, J. Y. (2008). A Well Grounded Education: The role of perception in science and mathematics (M. de Vega, A. Glenberg, \& A. Graesser Eds.) Symbols, embodiment, and meaning. New York: Oxford Press, 2008. [Online]. Tersedia di: http://learnersdictionary.com [Diakses 18 Juli 2015].

Howard, L. (2008). Developmental students' perceptions of unsuccessful and successful mathematics learning. Disertasi. Utah State University.

Howey, S. C. (13 Nopember 2014). Factors in student motivation. [Online]. Tersedia di: http://www.nacada.ksu.edu/Resources/Clearinghouse/ViewArticles/Motivation.aspx. [Diakses 10 Juli 2015].

Jen, C. S. \& Yong, B. C. S. (2013). Secondary School Students' Motivation and Achievement in Combined Science. US-China Education Review B 3(4): 213-228.

Kemboi, N. K., Githua, B. N., \& Changeiywo, J. M. (2014). The Relationship Between Students' Attitude Towards Mathematics And Their Mathematics Self-Concept And Achievement In The Military Science Programme Offered At Egerton University In Kenya. Journal of Education and Practice, 5(39), 2014: 56-63.

Lawellen, M. M. (2008). Exploring the Influence of Vocabulary Instruction on Students' Understanding of Mathematical Concepts. Action Research Projects, Paper 54. [Online]. Tersedia di: http://digitalcommons.unl. edu/ [Diakses 10 Juli 2015].

Mutodi, P. \& Ngirande, H. (2014). Exploring Students' Ability to Read Mathematics Text: Case Study of Selected Secondary Schools in the Limpopo Province. Journal Education and Science, 6(2), 2014: 392-393. 
Obilor, I. E. (2011). Interaction between self-concept, and mathematics, English language and general academic achievement of senior secondary students in Port Harcourt. Journal of Educational and Social Research 1(4), 2011: 39-46.

Rohman, F. \& Effendi, E. (2014). Hubungan antara Penguasaan Konsep Dasar Diferensial dan Integral dengan Prestasi Belajar Siswa pada Materi Kinematika dengan Analisis Vektor Kelas XI SMA dan MA Se-Kecamatan Buay Madang Kabupaten OKU Timur Tahun Pembelajaran 2012/2013. Prosiding Pertemuan Ilmiah XXVIII HFI Jateng \& DI Yogyakarta, 26 April 2014, hlm 70-73. [Online]. Tersedia di: http://hfi-diyjateng.or.id/sites/default/files/1/FULL-

Hubungan\%20antara\%20Penguasaan\%20Konsep\%20Dasar\%20Diferensial\%20dan \%20Integral\%20dengan\%20Prestasi\%20Belajar\%20Siswa\%20pada\%20Materi\%20 Kinematika\%20dengan\%20Analisis\%20Vektor\%20Kelas\%20XI\%20SMA\%20dan $\% 20 \mathrm{MA} \% 20 \mathrm{Se}-$

Kecamatan\%20Buay\%20Madang\%20Kabupaten\%20OKU\%20Timur\%20Tahun\% 20Ajaran\%202012/2013.pdf [Diakses 10 Juli 2015].

Samo, M. A. (2008). Students' perceptions about the symbols, letters and signs in algebra and how do these affect their learning of algebra: A case study in a government girls secondary school, Karachi, Pakistan. Tesis. Aga Khan University.

Sardiman, A. M. (2010). Interaksi dan Motivasi Belajar Mengajar. Jakarta: Rajawali Pers.

Simonson, S. \& Gouvea, F. (2015). How to Read Mathematics. [Online]. Tersedia di: web.stonehill.edu/compsci/history_math/math-read.htm. [Diakses 10 Januari 2016].

Spagnolo, C. S. F. (2003). The introduction of the symbolic language in secondary school: experimental analysis of a-didactic situation by Vigotskij semiotic tools. Proceedings of the International Conference The Decidable and the Undecidable in Mathematics Education, September 2003. [Online]. Tersedia di: http://math.unipa.it/ grim/ 21_project/21_brno03_SortinoSpagnolo.pdf. [25 Desember 2015].

Suriasumantri, J. (2010). Menguak Cakrawala Keilmuan, Landasan Filosofis Penulisan Tesis dan Desertasi. Jakarta: Program Pascasarjana Universitas Negeri Jakarta1.

Susuwele, W. J. (2005). Classroom Assessment in Malawi: Teachers' Perceptions and Practices in Mathematics. Unpublication Desertation. University of Virginia. [Online]. Tersedia di: http://scholar.lib.vt.edu/ [Diakses 14 Nopember 2015].

Tella, A. (2007). The Impact Of Motivation On Student's Academic Achievement and Learning Outcomes In Mathematics Among Secondary School Students In Nigeria. Eurasia. Journal of Mathematics, Science \& Technology Education, 3(2): 149-156.

Wenno, I. H. (2015). The Correlation Study of Interest at Physics and Knowledge of Mathematics Basic Concepts towards the Ability to Solve Physics Problems of 7 th Grade Students at Junior High School in Ambon Maluku Province, Indonesia. Education Research International Volume 2015, 1-6. [Online]. Tersedia di: https://www.hindawi.com/journals/edri/2015/396750/ [20 Desember 2015].

Windhani, K. \& Hardoyono, F. (2012). Analysis Of Student's Ability In Math Concepts As A Tool For Studying Economic Theory. Makalah Seminar Nasional Matematika dan Pendidikan Matematika dengan tema "Kontribusi Pendidikan Matematika dan Matematika dalam Membangun Karakter Gurru dan Siswa". Jurusan Pendidikan Matematika FMIPA UNY. 